\title{
Association of trace metals with various sedimentary phases in dam reservoirs
}

\author{
A. R. Karbassi; *F. Torabi; F. Ghazban; M. Ardestani \\ Department of Environmental Engineering, Graduate Faculty of the Environment, University of Tehran, Tehran, \\ Iran
}

Received 9 Februaty 2011; revised 9 July 2011; accepted 17 August 2011

\begin{abstract}
In the present study sediment and water samples collected from Kowsar Dam reservoir in Kohkiluye and Boyerahmad Province, southwest of Iran, are subjected to bulk digestion and chemical partitioning. The concentrations of nickel, lead, zinc, copper, cobalt, cadmium, manganese and iron in water and bed sediment were determined by atomic absorption spectrometry. The concentrations of metals bounded to five sedimentary phases were estimated. On this basis, the proportions of natural and anthropogenic elements were calculated. The anthropogenic portion of elements are as follows: $\operatorname{zinc}(96 \%)>\operatorname{cobalt}(88 \%)>\operatorname{iron}(78 \%)>$ magnesium $(78 \%)>\operatorname{nickel}(78 \%)>\operatorname{copper}(66 \%)>$ lead $(63 \%)>$ cadmium (59\%). The results show sediment contamination by nickel, cadmium and lead, according to the world aquatic sediments and mean earth crust values. Manganese and copper have strong association with organic matter and are of high portion of sulfide bounded ions. Finally, The degree of sediment contamination was evaluated using enrichment factor, geo-accumulation index (Igeo) and pollution index (IPoll). The sediments were identified to be of high cadmium and lead pollution index. The pattern of pollution intensity according to enrichment factor is as follows; manganese $(1.25)<$ copper $(1.63)<$ zinc $(1.93)<$ cobalt $(2.35)<\operatorname{nickel}(3.83)<$ lead $(12.63)<$ cadmium $(78.32)$. Cluster analysis was performed in order to assess heavy metal interactions between water and sediment. Accordingly, nickel, cadmium and copper are earth originated. Zinc, copper and manganese are dominated by $\mathrm{pH}$. All the elemental concentrations in water and sediment are correlated except for sedimental copper.
\end{abstract}

Keywords: Anthropogenic; Lithogenous; Sediment; Trace metals

\section{INTRODUCTION}

Dams are important structures from the environmental effects point of view. It has been proved that sediments entering a dam reservoir contain materials from neighboring geological formations and organic substances from plants and animal remains decomposed in water (Barretoo et al., 2008). The concentration of organic matter increases gradually in dam reservoir. The accumulation of organic substances can both affect the quality of reservoir water and change the oxidation state into anoxic condition. Reduction condition together with low $\mathrm{pH}$ will cause mobilization of metals to upper water levels (Biati et al., 2010). This may lead to serious changes in the water quality of the reservoir. Interactions commonly occur in the sediment-water interface (Van de Guchte, 1992; Chapman, 2000). As a result, investigation of

*Corresponding Author Email: fatemeh.torabi@gmail.com Tel.: +98912-8069018; Fax: +98 2166485096 both water and sediment quality is required to examine the quality of reservoir water.

Metal pollution is a serious problem in aquatic systems since their accumulation in the living organisms is toxic and environmentally nonbiodegradable (Forstner et al., 1990; Hart et al., 1991; Schuurmann and Market, 1998). Thus, studying water and sediment quality is important to evaluate metal concentrations, since it provides useful information on pollution level in a reservoir. This has already been investigated in various environmnets in several researches (Priju and Narayana, 2007; Opuene et al., 2008; Al-Juboury, 2009; Kho et al., 2009; Taghinia Hejabi et al., 2010). To assess the extent of sediments pollution, determination of the total heavy metal concentration is not sufficient. Identification of the chemical form of the metal in sediments is also required to determine the metal behavior and remobilization in the environment. In addition, the extent of 
contamination can be understood by the determination of the metals distribution between different phases and their origins (natural or anthropogenic) (Forstner, 1985). The five sedimentary phases are: 1) Loosely, 2) Sulfide, 3) Organic-metallic, 4) Resistant, and 5) Within lattice bounded ions.

To evaluate heavy metal loads, usually establishing the contributions of heavy metals in various soluble fractions is also required. These fractions are commonly quantified by a sequential extraction procedure (Horowitz et al., 1999; stamatis et al., 2006).

Kowsar Dam has been constructed on Kheirabad River in Kohkiluye and Boyerahmad Province, southwest of Iran, in 2004. Sampling was carried out in an area between the longitudes of $50^{\circ} 39^{\prime} \mathrm{W}$ and $50^{\circ}$ $43^{\prime}$ E and latitudes of $30^{\circ} 35^{\prime} \mathrm{S}$ and $30^{\circ} 38^{\prime} \mathrm{N}$ ( Fig. 1).

The main goals of the current investigation are: 1) To assess the extent of metals concentrations and their origin and speciation; 2) To identify the association of metals with different sedimentary phases and; 3 ) To evaluate the aquatic system pollution using Muller's geochemical index $\left(\mathrm{I}_{\text {geo }}\right)$, pollution index $\left(\mathrm{I}_{\mathrm{POLL}}\right)$ and enrichment factor $(\mathrm{EF})$.

The metals selected for the present study include $\mathrm{Ni}, \mathrm{Pb}, \mathrm{Zn}, \mathrm{Cu}, \mathrm{Co}, \mathrm{Cd}, \mathrm{Mn}$ and Fe. Furthermore, Loss on ignition (LOI) and $\mathrm{pH}$ for sediments were also selected for this investigation.

This research was carried out in the Faculty of Environment laboratory, University of Tehran, between October 2010 and February 2011.

\section{MATERIALS AND METHODS}

Twelve sediment samples were collected from different stations in the bottom of the dam reservoir. Also, water samples were collected from the surface, middle depth and bottom in each station. Sampling was carefully performed by professional divers, with the least disturbance in sediment layer. Water samples were stored in $1000 \mathrm{~mL}$ polyethylene containers, previously rinsed with the water of the site. The brown to blackcolored sediment samples were dried in oven at $50^{\circ} \mathrm{C}$ and passed through a $63-\mu \mathrm{m}$ mesh (ASTM E-11).

About $0.5 \mathrm{~g}$ of sediment sample was placed in a beaker and reacted with $0.1 \mathrm{~mL}$ of $1 \mathrm{~N} \mathrm{HCl}$. As the first step of bulk digestion, $7 \mathrm{~mL}$ of a mixture of $\mathrm{HCl}$ and $\mathrm{HNO}_{3}(1: 3)$ was added. Subsequently, the mixture was heated on a sand bath at $125{ }^{\circ} \mathrm{C}$, and brought into complete evaporation. To dissolve organic bounds, 7 $\mathrm{mL}$ of $\mathrm{H}_{2} \mathrm{O}_{2}$ was added and the flask was placed on heat until it was almost dried. This was followed by the
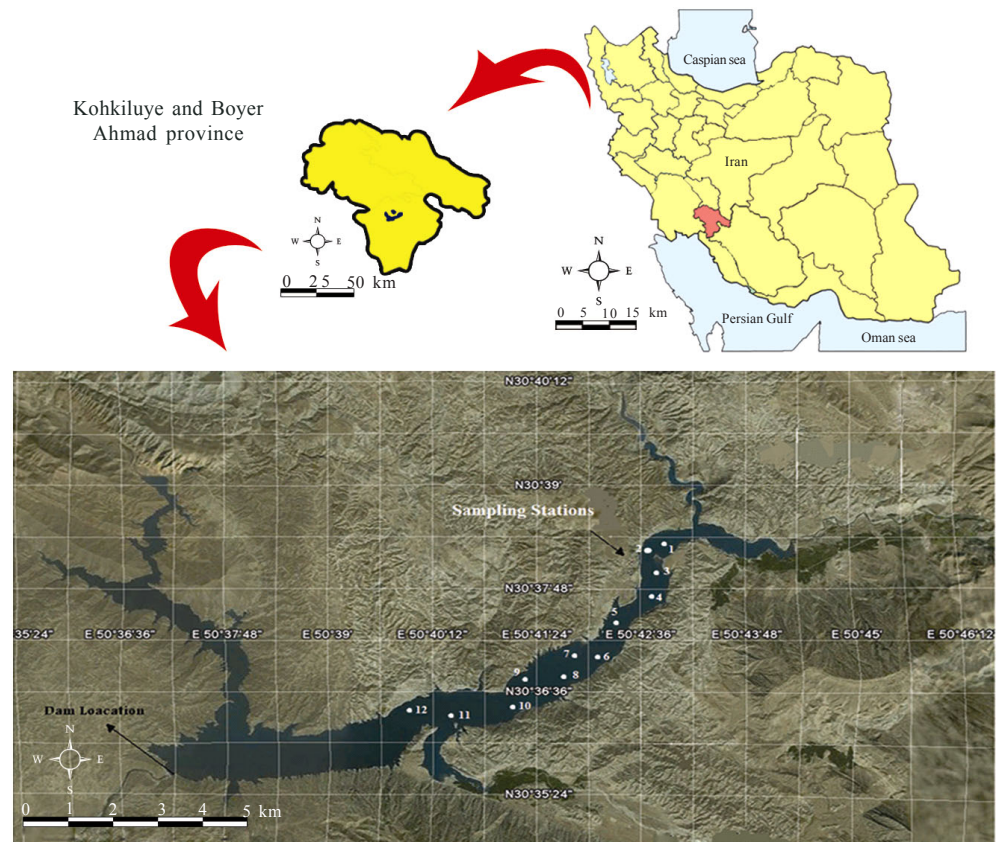

Fig. 1: Location map of Kowsar Dam reservoir in Kohkiluye and Boyer Ahmad province, Iran and the sampling sites 
addition of additional $4 \mathrm{~mL}$ of $\mathrm{H}_{2} \mathrm{O}_{2}$, and the sample was allowed to dry. Subsequently, the samples were allowed to cool down to room temperature, then transferred to $50 \mathrm{~mL}$ volumetric flasks and brought to volume with distilled water. The samples were further filtered through Whatman $.045 \mu \mathrm{m}$ membrane filters, and stored at $4{ }^{\circ} \mathrm{C}$ (Jain et al., 2005).

Chemical partitioning studies were also conducted. The following four steps were implemented: 1) Acetic acid $25 \% \mathrm{v} / \mathrm{v}, 2$ ) Acetic acid $25 \% \mathrm{v} / \mathrm{v}-0.1 \mathrm{M}$ hydroxylamine hydrochloride, 3) $30 \% \mathrm{H}_{2} \mathrm{O}_{2}$, and 4) Hot $50 \% \mathrm{HCl}$ (Gibs, 1973). To assure the accuracy of the results, all containers used for laboratory works were soaked in dilute $\mathrm{HNO}_{3}$ overnight and rinsed with distilled water prior to use. All acids used in this study were Merck analytical reagent, which supplies the accuracy required for the experiments.

The analysis of metals (i.e., $\mathrm{Ni}, \mathrm{Pb}, \mathrm{Zn}, \mathrm{Cu}, \mathrm{Co}, \mathrm{Cd}$, $\mathrm{Mn}$ and $\mathrm{Fe}$ ) present in water and sediment samples was carried out using a flame atomic absorption spectrophotometer (model 119 UNICAM).

Blanks and duplicates were run alongside with the samples. The analytical accuracy was approximately $\pm 5 \%$ for all elements. Organic matter was determined by measuring the LOI of samples heated for $4 \mathrm{~h}$ at $450^{\circ} \mathrm{C}$ in a muffle furnace (Carver, 1972).

Cluster analysis was carried out to determine the interrelationship amongst various parameters by the Weighted pair group method (WPG) (Davis, 1973) using MVSP software.

The speciation of the elements was also determined to identify the metal species existing in the water and sediment samples. Eh-pH diagrams were produced by the utilization of metal concentrations and molality and the sampling point's pressure (determined according to the elevation from sea level) in the HSC-Chemistry software. Using the output charts and oxidativereductive potential (Eh) values measured by a digital voltmeter for the samples, the species present in sediment and water samples were determined.

$I_{\text {geo, }}, I_{\text {POLL }}$ and EF were computed in order to determine the pollution intensity of the Dam sediment using the following formulae:

$$
\begin{aligned}
& I_{\text {geo }}=\log _{2}\left[\frac{C n}{B n x 1.5}\right] \\
& I_{\text {Poll }}=\log _{2}\left[\frac{C n}{B n}\right]
\end{aligned}
$$

Where $\mathrm{I}_{\text {geo }}$ is the geochemical accumulation index, $\mathrm{C}_{\mathrm{n}}$ is the metal concentration in sediment and $\mathrm{B}_{\mathrm{n}}$ is the metal concentration in shale (Mediolla et al., 2008). $\mathrm{I}_{\mathrm{POLL}}$ is the pollution index, an optimized form of $\mathrm{I}_{\mathrm{geo}}$ (Asaah et al., 2005).

Seven contamination ranges have been determined to assess the metal pollution status (Martin and Meybeck, 1979):

Igeo $\leq 0$ means unpolluted

$0<$ Igeo $<1$ means unpolluted to moderately polluted

$1 \leq$ Igeo $<2$ means moderately polluted

$2 \leq$ Igeo $<3$ means moderately to strongly polluted

$3 \leq$ Igeo $<4$ means strongly polluted

$4 \leq$ Igeo $<5$ means strongly to very strongly polluted Igeo $\geq 5$ means very strongly polluted

Another approach to estimate the amount of pollution in sediment is to compute the Enrichment factor (EF) using the following formula (Karbassi et al., 2008):

$\mathrm{EF}=\left[\mathrm{C}_{\text {metal }} / \mathrm{C}_{\mathrm{Fe}}\right]_{\text {sediment }} /\left[\mathrm{C}_{\text {metal }} / \mathrm{C}_{\mathrm{Fe}}\right]_{\text {control }}$

Where $\mathrm{C}_{\text {metal }}$ and $\mathrm{C}_{\mathrm{Fe}}$ are the concentrations of metal and $\mathrm{Fe}$ in sediments of present study and in an unpolluted environment (the earth crust) (Huu et al., 2010). The pollution intensity is to be evaluated by the following categorizations for EF (Karbassi et al., 2008):

$\mathrm{EF}<2$ is deficiency to minimal enrichment

EF 2-5 is moderate enrichment

EF 5-20 is significant enrichment

EF 20-40 is very high enrichment

$\mathrm{EF}>40$ is extremely high enrichment

Larger EF values show more contribution of the anthropogenic origins (Sutherland, 2000).

\section{RESULTS AND DISCUSSION}

Elemental concentrations ( $\mathrm{Ni}, \mathrm{Cd}, \mathrm{Zn}, \mathrm{Pb}, \mathrm{Cu}, \mathrm{Co}$, $\mathrm{Mn}$ and $\mathrm{Fe}$ ), along with organic matter content (LOI) and physico-chemical properties in sediment are presented in Table 1. The measured values are compared with the values from Earth crust and world sediments (Turekian and Wedepohl, 1961; Bowen, 1979). The mean concentrations of $\mathrm{Ni}$ and $\mathrm{Pb}$ in Kowsar Dam sediments were found to be considerably higher than that of these metals in aquatic sediments. The mean concentrations of $\mathrm{Cd}$ and $\mathrm{Pb}$ are also higher than the metals in mean earth crust (Bowen, 1979).

The results of the five-step sequential chemical partitioning are presented in Table 2. The percentages 
Metals in dam reservoirs

Table 1: Concentration of metals and physical properties in Kowsar Dam bed sediments

\begin{tabular}{|c|c|c|c|c|c|c|c|c|c|c|c|}
\hline \multirow{2}{*}{ Station No. } & $\mathrm{Ni}$ & $\mathrm{Cd}$ & $\mathrm{Zn}$ & $\mathrm{Pb}$ & $\mathrm{Cu}$ & $\mathrm{Co}$ & $\mathrm{Mn}$ & \multirow{2}{*}{$\frac{\mathrm{Fe}}{\%}$} & LOI & \multirow{2}{*}{$\begin{array}{c}\mathrm{Eh} \\
\mathrm{mV}\end{array}$} & \multirow[t]{2}{*}{$\mathrm{pH}$} \\
\hline & $\mathrm{mg} / \mathrm{kg}$ & & & & & & & & & & \\
\hline 1 & 83 & 6 & 35 & 40 & 25 & 11 & 250 & 1.26 & 4.04 & -189 & 6.46 \\
\hline 2 & 82 & 6 & 40 & 38 & 17 & 13 & 270 & 1.22 & 4.15 & -180.2 & 7.23 \\
\hline 3 & 57 & 5 & 30 & 50 & 17 & 10 & 250 & 0.86 & 70.49 & -160.3 & 6.8 \\
\hline 4 & 76 & 5.5 & 33 & 40 & 24 & 12 & 250 & 0.94 & 4.22 & -169.2 & 6.59 \\
\hline 5 & 60 & 6 & 30 & 39 & 19 & 12 & 250 & 1.12 & 26.15 & -185.2 & 6.92 \\
\hline 6 & 70 & 5.5 & 38 & 39 & 19 & 10 & 250 & 1.14 & 4.1 & -184.1 & 7.15 \\
\hline 7 & 82 & 5.5 & 37 & 48 & 19 & 11.5 & 260 & 1.20 & 51.91 & -177.1 & 7.20 \\
\hline 8 & 69 & 6 & 40 & 41 & 22 & 12.5 & 260 & 0.89 & 21 & -180.9 & 6.49 \\
\hline 9 & 77 & 6 & 32 & 39 & 23 & 13 & 250 & 0.99 & 64.7 & -163.9 & 7.10 \\
\hline 10 & 67 & 5.5 & 35 & 43 & 17 & 10 & 269 & 1.23 & 4.48 & -186 & 6.56 \\
\hline 11 & 82 & 5 & 36 & 50 & 17 & 11 & 260 & 1.26 & 4.16 & -162.4 & 6.50 \\
\hline 12 & 83 & 6 & 34 & 45 & 17 & 10 & 261 & 1.25 & 55.34 & -179.7 & 6.94 \\
\hline Min & 57 & 5 & 30 & 38 & 17 & 10 & 250 & 0.86 & 4.04 & -189 & 6.46 \\
\hline Max & 83 & 6 & 40 & 50 & 25 & 13 & 270 & 1.26 & 70.49 & -160.3 & 7.23 \\
\hline Mean & 74 & 5 & 35 & 42.7 & 19.7 & 11.3 & 256.7 & 1.11 & 26.23 & -176.5 & 6.83 \\
\hline Earth crust* & 80 & 0.3 & 75 & 14 & 50 & 20 & 850 & 4.6 & & & \\
\hline World sediments* & 52 & - & 95 & 19 & 33 & 14 & 770 & 4.1 & & & \\
\hline
\end{tabular}

of elements associated with different sedimentary phases are as follows:

Loose ions:

$\mathrm{Cd}(54 \%)>\mathrm{Co}(48 \%)>\mathrm{Pb}(43 \%)>\mathrm{Mn}(38 \%)>\mathrm{Cu}$ $(29 \%)>\mathrm{Zn}(28 \%)>\mathrm{Ni}(17.9 \%)>\mathrm{Fe}(8 \%)$

Sulfide ions:

$\mathrm{Mn}(22 \%)>\mathrm{Cu}(21 \%)>\mathrm{Zn}(10 \%)>\mathrm{Fe}(7 \%)>\mathrm{Co}(6 \%)>$ $\mathrm{Pb}(2 \%)>\mathrm{Ni}(1.75 \%)>\mathrm{Cd}(1 \%)$

Organic-metallic ions:

$\mathrm{Pb}(22 \%)>\mathrm{Fe}(22 \%)>\mathrm{Mn}(19 \%)>\mathrm{Cd}(8 \%)>\mathrm{Ni}$ $(7.5 \%)>\mathrm{Co}(7 \%)>\mathrm{Zn}(5 \%)>\mathrm{Cu}(2 \%)$

Resistant ions:

$\mathrm{Zn}(57 \%)>\mathrm{Fe}(50 \%)>\mathrm{Ni}(38 \%)>\mathrm{Co}(34 \%)>\mathrm{Cu}$ $(24 \%)>\operatorname{Mn}(8 \%)>\mathrm{Cd}(6 \%)>\mathrm{Pb}(6 \%)$

Within lattice: $\mathrm{Cd}(31 \%)>\mathrm{Pb}(27 \%)>\mathrm{Cu}(24 \%)>\mathrm{Fe}$ $(13 \%)>\operatorname{Mn}(13 \%)>\operatorname{Ni}(8.8 \%)>\operatorname{Co}(5 \%)>\operatorname{Zn}(0 \%)$

The results are also illustrated in Fig. 2.

As it is expected according to several studies (Turekian and Wedepohl, 1961; De, 1987), Mn (22 \%) and $\mathrm{Cu}(21 \%)$ as cationic metals have strong associations with organic matter, because of their relatively high portions of sulfide bounded ions.

Furthermore, the anthropogenic and lithogenus shares of the metals were calculated by summing up the loosely, sulfide and organic bounded ions (Fig. 3). The following pattern shows the mean anthropogenic portions of the studied metals, as a percentage of their mean concentrations:

$\mathrm{Zn}(96 \%)>\mathrm{Co}(88 \%)>\mathrm{Fe}(78 \%)>\mathrm{Mn}(78 \%)>\mathrm{Ni}$ $(78 \%)>\mathrm{Cu}(66 \%)>\mathrm{Pb}(63 \%)>\mathrm{Cd}(59 \%)$. Based on $\mathrm{I}_{\text {geo }}$ and the EF (Table 3), the level of pollution in the study area was determined using mean concentrations of metals in the aquatic sediments of the dam. The pollution intensity pattern according to $\mathrm{EF}$ is as follows: $\mathrm{Mn}(1.25)<\mathrm{Cu}(1.63)<\mathrm{Zn}(1.93)<\mathrm{Co}(2.35)<$ $\mathrm{Ni}(3.83)<\mathrm{Pb}(12.63)<\mathrm{Cd}$ (78.32). According to the aforementioned $\mathrm{EF}$ categorizations, $\mathrm{Pb}$ and $\mathrm{Cd}$ are of "significant" and "very high" enrichment levels while the rest are of minimal to moderate pollution levels. The $\mathrm{I}_{\text {geo }}$ and $\mathrm{I}_{\mathrm{POLL}}$ results are partially compatible with the EF results. According to these measures, the sediments are strongly polluted by $\mathrm{Cd}$, while the remaining elements fall within their natural ranges respectively.

Dendogram of cluster analysis (Fig. 4) shows that $\mathrm{Ni}, \mathrm{Cd}, \mathrm{Fe}$ and $\mathrm{Cu}$ form cluster "A" show similar behavior. Since nickel is an indicator of oil pollution, it can be concluded that the concentrations of $\mathrm{Cd}, \mathrm{Cu}$ and $\mathrm{Fe}$ are due to contamination by oil. This is supported by the fact that the Gachsaran oil field is located about $30 \mathrm{~km}$ from the reservoir. Since iron is known to be a lithogenous index, it can be also concluded that $\mathrm{Ni}, \mathrm{Cd}$ and $\mathrm{Cu}$ are originated from the earth crust. This interpretation is compatible with the results of partitioning (Fig. 3), as the lithogenous portion of $\mathrm{Cu}$ and $\mathrm{Cd}$ contents is significantly high compared to other elements.

There is also a high correlation between $\mathrm{pH}$ and $\mathrm{Zn}$, $\mathrm{Co}$, and $\mathrm{Mn}$ in cluster "B". This indicates that these elements are mainly governed by the $\mathrm{pH}$ of sediments.

In cluster "C" LOI and lead strongly correlate with the Eh of the sediments. This firstly defines the effect of organic matters on the Eh value, which is related to 
Int. J. Environ. Sci. Tech., 8 (4), 841-852, Autumn 2011

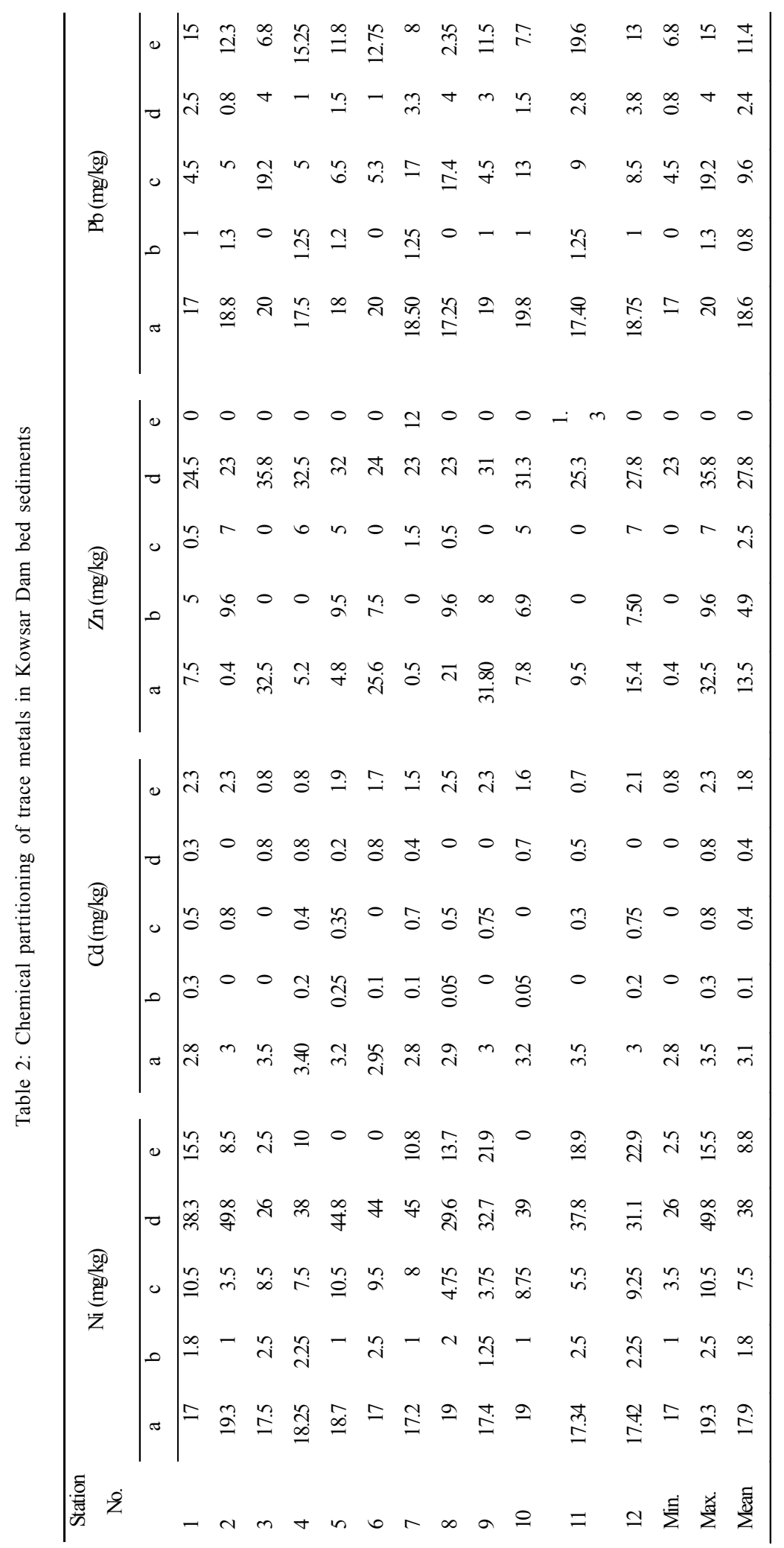


anoxic environment, and secondly shows the organic source of $\mathrm{Pb}$ in the sediment. This is compatible with the results of chemical partitioning indicating that 22 $\%$ of total $\mathrm{Pb}$ content is bounded to organic ions.

The presence of $\mathrm{Mn}, \mathrm{Co}, \mathrm{Zn}$, and $\mathrm{Pb}$ in a separate cluster from $\mathrm{Fe}$ can also show that these elements are not earth-originated. Partitioning results are also consistent with this.

The speciation of metals by HSC Chemistry software is indicative of the presence of the following species in sediments:

$\mathrm{NiO}, \mathrm{Cd}^{2+}, \mathrm{Zn}^{2+}, \mathrm{Pb}(\mathrm{OH})^{+}, \mathrm{Cu}, \mathrm{Mn}^{2+}, \mathrm{Fe}_{3} \mathrm{O}_{4}, \mathrm{Co}(\mathrm{OH})_{2}$.

According to HSC Chemistry software, the speciation of metals in water is as follows:

$\mathrm{Fe}_{3} \mathrm{O}_{4}, \mathrm{Mn}^{2+}, \mathrm{Co}(\mathrm{OH})_{2}, \mathrm{Co}(\mathrm{OH})^{+}, \mathrm{Cu}, \mathrm{Pb}(\mathrm{OH})^{+}, \mathrm{Zn}^{2+}$, $\mathrm{NiO}, \mathrm{Cd}^{2+}$.

Therefore, it can be noted that the speciation of metals within the water column and sediments are somehow alike. This is clearly indicative of active water rock inter-action in the area of study. Here are some definitions about the aforementioned species, contributing to determine their characteristics in sediment and water:

Nickel (II) oxide is notable as being the only well characterized oxide of nickel. Several million kilograms are produced in varying quality annually, mainly as an intermediate in the production of nickel alloys (Rosental et al., 1986).

Cadmium prefers oxidation state +2 in most of its compounds. It occurs as a byproduct of zinc production (Lascelles et al., 2005). Cadmiumcontaining ores are rare and are found to occur in small quantities. However, traces do naturally occur in phosphate, and have been shown to transmit in food through fertilizer application (Kirk and Othmer, 1985).

The only common oxidation state of zinc is +2 . The element is normally found in association with other base metals such as copper and lead in ores. The dumps of the past mining operations leach significant amounts of zinc and cadmium. It is also used for galvanization process (Jiao et al., 2004).

The hydrolysis of $\mathrm{Pb}^{2+}$, under progressively increasing alkaline conditions, forms $\mathrm{Pb}(\mathrm{OH})^{+}$, $\mathrm{Pb}(\mathrm{OH})_{2}$ (aqueous), $\mathrm{Pb}(\mathrm{OH})_{3}^{-}$, and other species, including several polynuclear species (Broadley et al., 2007). Metallic lead does occur in nature, but it is rare. Lead is usually found in ore with zinc, silver and (most abundantly) copper and is extracted together with these metals (Wiberg et al., 2001) .

Manganese is found as a free element in nature (often in combination with iron), and in many minerals. As a free element, manganese is a metal with important industrial metal alloy uses, particularly in stainless steels and as an electrode in dry cells. The most stable oxidation state for manganese is +2 (Samans, 1949).

$\mathrm{Fe}_{3} \mathrm{O}_{4}$ is a ferrimagnetic mineral commonly known as Magnetite, one of several iron oxides and a member of the spinel group. Small grains of magnetite occur in almost all igneous and metamorphic rocks. Magnetite also occurs in many sedimentary rocks, including banded iron formations (Rayner-Canham and Overton, 2003).

Cobalt (II) hydroxide is the chemical compound composed of cobalt and the hydroxide ion (Harrison et $a l ., 2002)$. It finds the usage as a drying agent for paints, varnishes and inks, in the preparation of other cobalt compounds, as a catalyst, or in the manufacture of battery electrodes (Lide, 1998).

Results of water metal concentrations in the three aforementioned depths are presented in Fig. 5. Although the general trend of the concentrations seems to be ascending from the surface to the bottom level of water in the diagrams, there are still some exceptions such as $\mathrm{Ni}, \mathrm{Cd}$ and $\mathrm{Co}$. This may indicate that the concentration of most of the metals at the bottom of the reservoir is more than that of metals in the surface. Thus, it is concluded that the concentration of metals accumulated in the water adjacent to sediment layer is more, compared with the accumulation in other water levels.

Therefore, it can be noted that the speciation of metals within the water column and sediments are somehow alike. This is clearly indicative of active water rock inter-action in the area of study. Here are some definitions about the aforementioned species,

Table 3: Comparison of various pollution indices in Kowsar Dam bed sedimants

\begin{tabular}{ccrrr}
\hline Metal & $\begin{array}{c}\text { Mean concentration } \\
(\mathrm{mg} / \mathrm{Kg})\end{array}$ & $I_{\text {geo }}$ & $\mathrm{EF}$ & $I_{\text {Poll }}$ \\
\hline $\mathrm{Ni}$ & 74 & -0.46 & 3.83 & 0.12 \\
$\mathrm{Cd}$ & 5.67 & 3.66 & 78.32 & 4.24 \\
$\mathrm{Zn}$ & 35 & -2.03 & 1.93 & -1.44 \\
$\mathrm{~Pb}$ & 42.67 & - & 12.63 & - \\
$\mathrm{Cu}$ & 19.67 & -1.78 & 1.63 & -1.19 \\
$\mathrm{Co}$ & 11.33 & -1.33 & 2.35 & -0.75 \\
$\mathrm{Mn}$ & 256.67 & -2.31 & 1.25 & -1.73 \\
\hline
\end{tabular}


$\mathrm{Ni}$

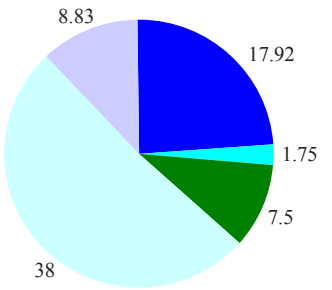

- Lo o s ly bo nded

Sulfide bonded

- Organic-metalic bonded Res is tant bonded

Within lattice bonded

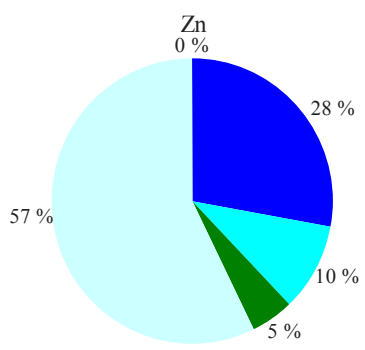

Looslybonded

Sulfide bonded

- Organic-metalic bonded Resis tant bonded

Within lattice bonded

$\mathrm{Cu}$

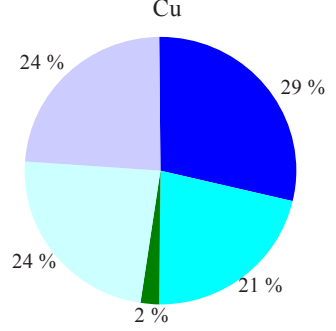

Lo o s ly bo nded

Organic-metalic bonded

Within lattice bo nded

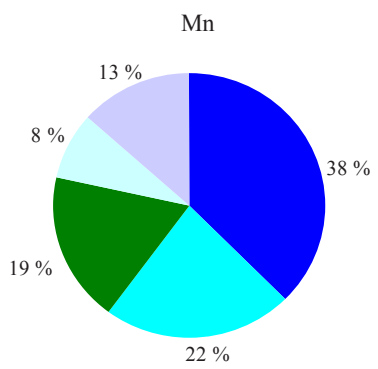

Lo o s ly bo nded

Sulfide bo nded

Organic-metalic bonded Res istant bonded

Within lattice bonded
$\mathrm{Cd}$

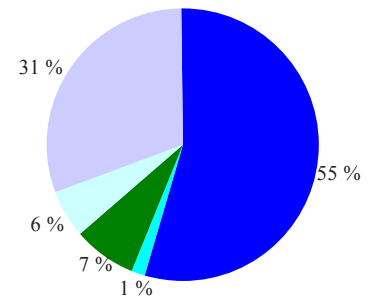

- Lo o s ly bo nded Sulfide bo nded Organic-metalic bonded Res is tant bonded Within lattice bonded

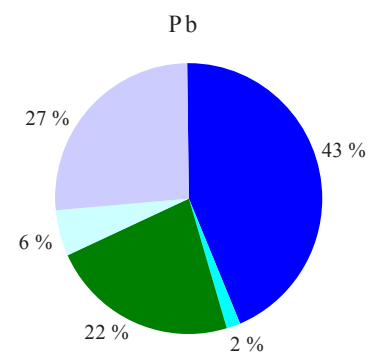

- Lo o s ly bonded

Sulfide bonded - Organic-metalic bonded Res istant bonded Within lattice bonded

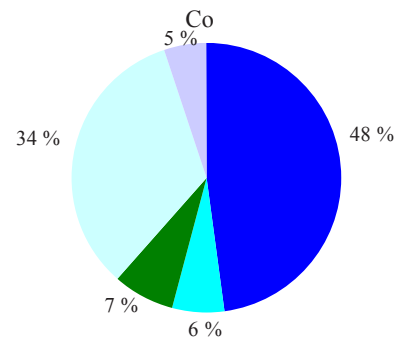

- Loos ly bonded

Sulfide bonded

Organic-metalic bonded Resistant bonded Within lattice bonded

$\mathrm{Fe}$

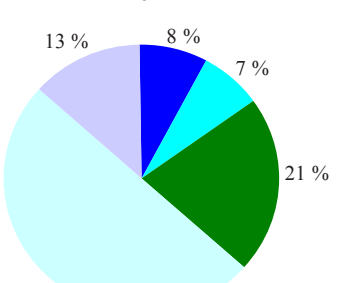

$51 \%$

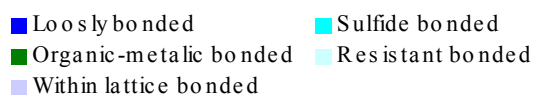

- Organic-metalic bonded Res istant bonded Within lattice bonded

Fig. 2: Association of metals with various sedimentary phases in Kowsar Dam 
Metals in dam reservoirs
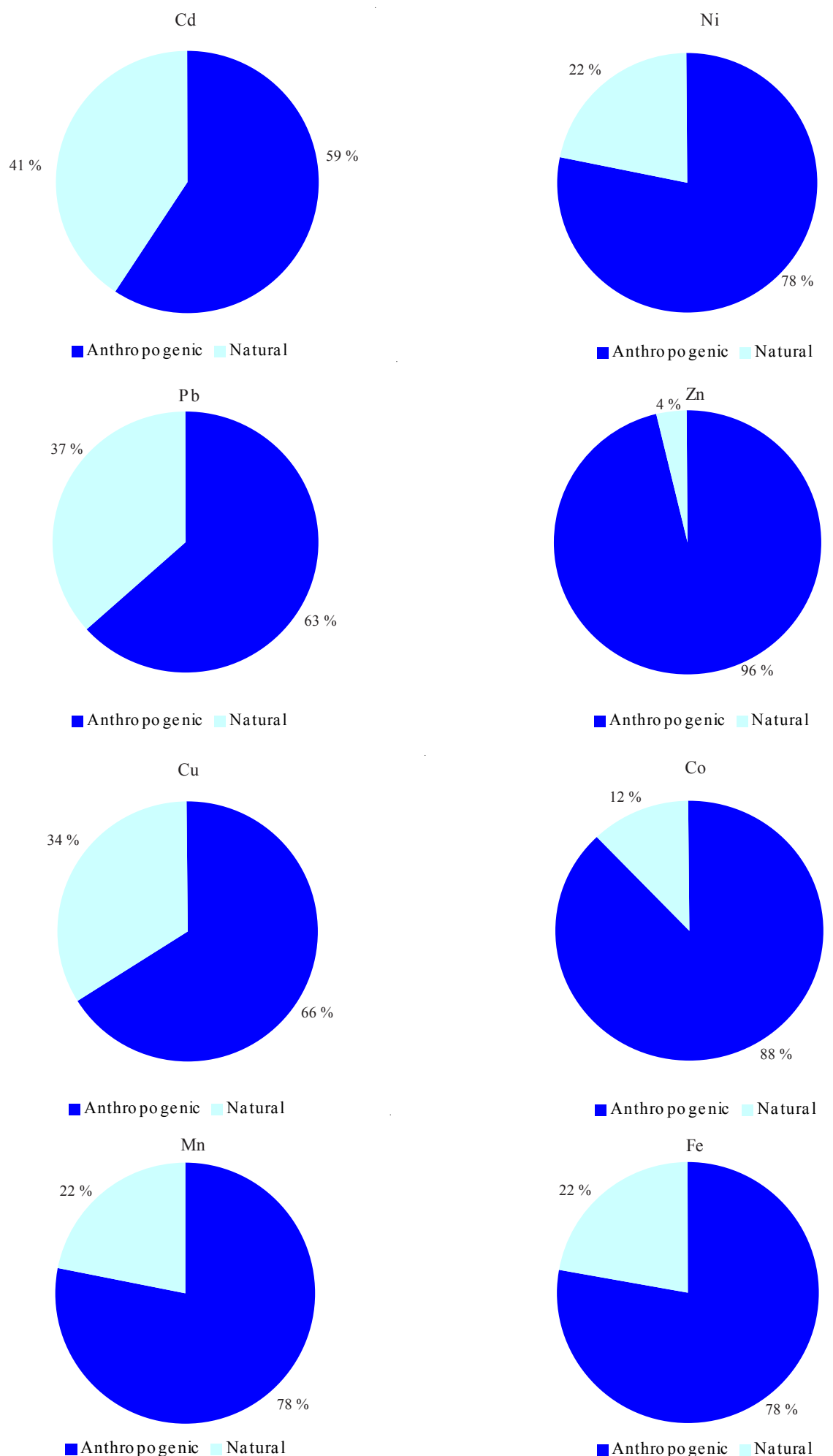

- Anthropogenic Natural

- Anthropogenic Natural

Fig. 3: Pie diagrams showing natural and anthropogenic portions of metals in the bottom sediments of Kowsar Dam 
contributing to determine their characteristics in sediment and water:

Nickel (II) oxide is notable as being the only well characterized oxide of nickel. Several million kilograms are produced in varying quality annually, mainly as an intermediate in the production of nickel alloys (Rosental et al., 1986).

Cadmium prefers oxidation state +2 in most of its compounds. It occurs as a byproduct of zinc production (Lascelles et al., 2005). Cadmiumcontaining ores are rare and are found to occur in small quantities. However, traces do naturally occur in phosphate, and have been shown to transmit in food through fertilizer application (Kirk and Othmer, 1985).

The only common oxidation state of zinc is +2 . The element is normally found in association with other

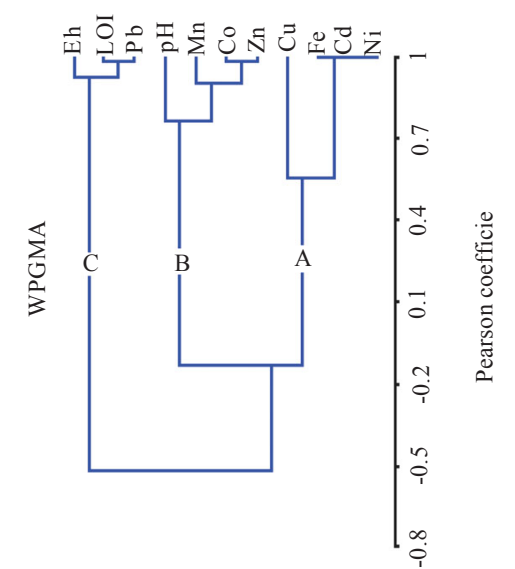

Fig. 4: Dendogram of cluster analysis amongst trace metals in Kowsar Dam bed sediments

$\mathrm{Ni}(\mathrm{m}$ ic ro $\mathrm{g} / \mathrm{L})$ - wa ter depth

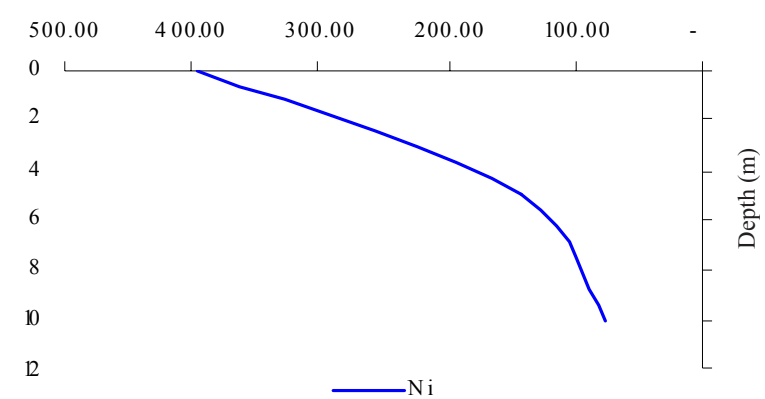

base metals such as copper and lead in ores. The dumps of the past mining operations leach significant amounts of zinc and cadmium. It is also used for galvanization process (Jiao et al., 2004).

The hydrolysis of $\mathrm{Pb}^{2+}$, under progressively increasing alkaline conditions, forms $\mathrm{Pb}(\mathrm{OH})^{+}$, $\mathrm{Pb}(\mathrm{OH})_{2}$ (aqueous), $\mathrm{Pb}(\mathrm{OH})_{3}{ }^{-}$and other species, including several polynuclear species (Broadley et al., 2007). Metallic lead does occur in nature, but it is rare. Lead is usually found in ore with zinc, silver and (most abundantly) copper, and is extracted together with these metals (Wiberg et al., 2001) .

Manganese is found as a free element in nature (often in combination with iron), and in many minerals. As a free element, manganese is a metal with important industrial metal alloy uses, particularly in stainless steels and as an electrode in dry cells. The most stable oxidation state for manganese is +2 (Samans, 1949).

$\mathrm{Fe}_{3} \mathrm{O}_{4}$ is a ferrimagnetic mineral commonly known as Magnetite, one of several iron oxides and a member of the spinel group. Small grains of magnetite occur in almost all igneous and metamorphic rocks. Magnetite also occurs in many sedimentary rocks, including banded iron formations (Rayner-Canham and Overton, 2003).

Cobalt (II) hydroxide is the chemical compound composed of cobalt and the hydroxide ion (Harrison et al., 2002). It finds use as a drying agent for paints, varnishes, and inks, in the preparation of other cobalt compounds, as a catalyst, or in the manufacture of battery electrodes (Lide, 1998).

Results of water metal concentrations in the three aforementioned depths are presented in Fig. 5. Although the general trend of the concentrations seems to be ascending from the surface to the bottom

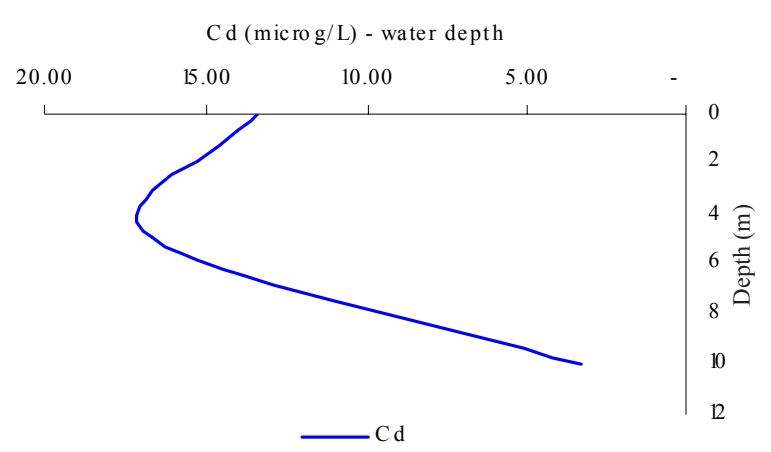

Fig. 5: Diagrams of water metal concentrations in various water depths of Kowsar Dam 


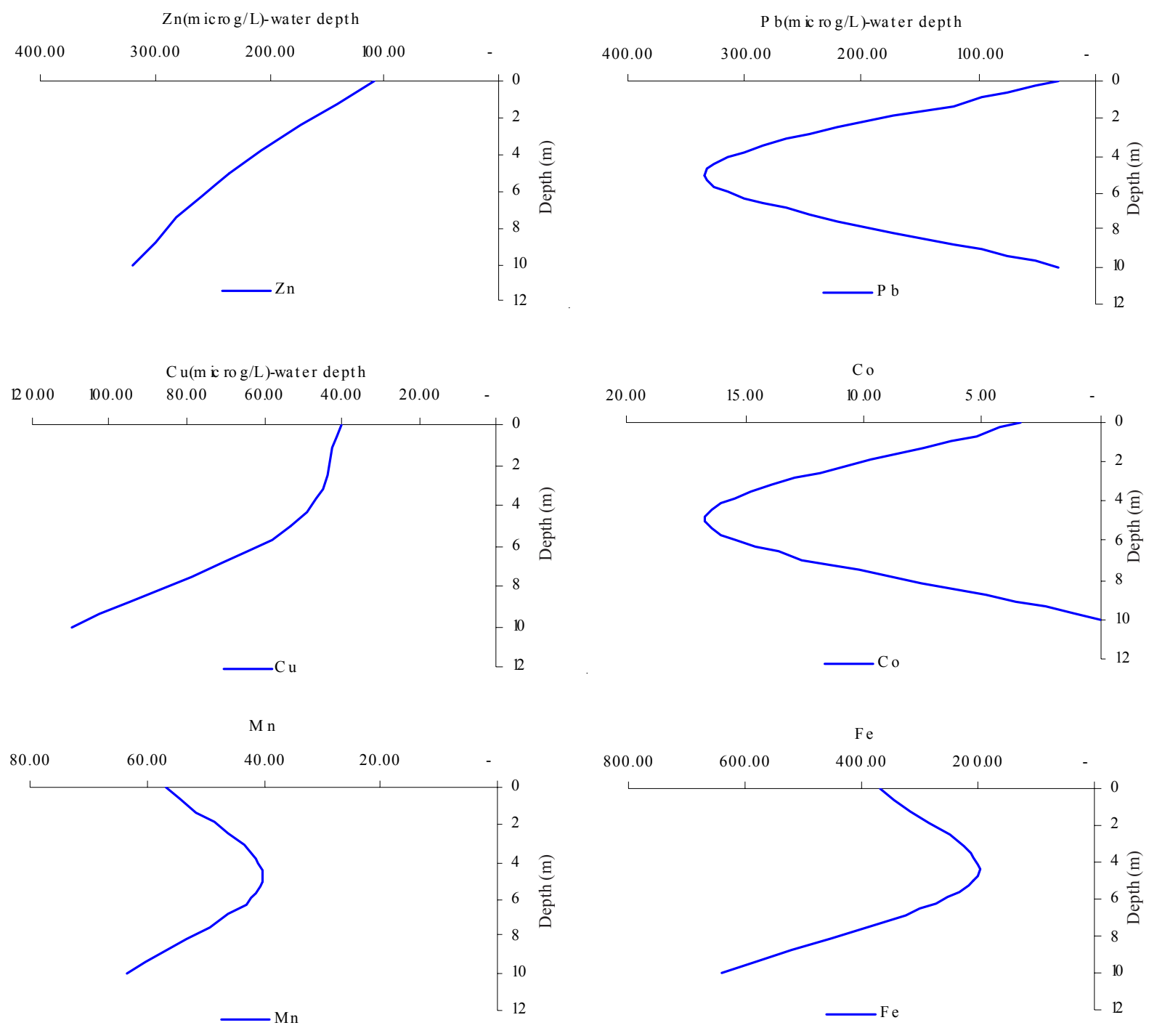

Fig. 5 (continues): Diagrams of water metal concentrations in various water depths of Kowsar Dam

level of water in the diagrams, there are still some exceptions such as $\mathrm{Ni}, \mathrm{Cd}$ and $\mathrm{Co}$. This may indicate that the concentration of most of the metals at the bottom of the reservoir is more than that of metals in the surface. Thus, it is concluded that the concentration of metals accumulated in the water adjacent to sediment layer is more, compared with the accumulation in other water levels.

\section{CONCLUSION}

Based on the results of this study, the portions of all metals bounded to anthropogenic phase were higher than that of them bounded to natural phase in sediments. This exhibits that a great portion of metal contents originates from anthropogenic origins such as municipal wastewater discharges to the reservoir rather than lithogenous origins. Sediments are contaminated with $\mathrm{Ni}, \mathrm{Cd}$ and $\mathrm{Pb}$ when compared to the world sediments and mean earth crust. Strong association of $\mathrm{Mn}$ and $\mathrm{Cu}$ with organic matter shows that these elements tend for organo metallic bounds. The higher concentrations of $\mathrm{Cd}$ and $\mathrm{Pb}$ are clearly shown by various pollution indices. According to the cluster analysis, $\mathrm{Ni}, \mathrm{Cd}$ and $\mathrm{Cu}$ are lithogenous, i. e 
originate from sources such as neighboring terrestrial formations. This clearly shows that in the absence of chemical partitioning studies, the statistical analysis may lead to wrong interpretations.

$\mathrm{Zn}, \mathrm{Co}$ and $\mathrm{Mn}$ are governed by $\mathrm{pH}$. All elemental concentrations in water and sediment are correlated with each other (except for $\mathrm{Cu}$ content of sediments). $\mathrm{Cd}, \mathrm{Fe}$ and $\mathrm{Cu}$ are due to oil contamination with the provenance of Gachsaran oil field near the reservoir. Since the speciation of metals within the water column and sediments are somehow alike, it might be inferred that equilibrium exists as a result of water rock interaction in the area of study.

\section{ACKNOWLEDGEMENTS}

The authors acknowledge the contributions of Yasooj Regional Water Institute to the data collection process. The authors have declared no conflict of interest.

\section{REFERENCES}

Al-Juboury, A. I., (2009). Natural pollution by some heavy metals in the Tigris River, northern Iraq. Int. J. Environ. Res., 3 (2), 189-198 (10 pages).

Asaah, V. A.; Abimbola, A. F.; Suh, C. E., (2005). Heavy metal concentrations and distribution in surface soils of the Bassa Industrial Zone 1, Doula, Cameroon. J. Sci. Eng., 31 (2A), 147 - 158 (12 pages).

Barretoo, W. J.; Ishikawa, D. N.; Scarminio, I. S.; Costa, J. S., (2008). Fe, Mn, P and S speciation in sediments from the Capivara Hydroelectric dam lake (Brazil) as an indicator of anthropogenic influences. Clean Soil, Air, Water, 36 (4), 353-359 (7 pages).

Biati, A.; Karbassi, A. R.; Hassani, A. H.; Monavari, S. M.; Moattar, F., (2010). Role of metal species in flocculation rate during estuarine mixing. Int. J. Environ. Sci. Tech., 7 (2), 327-336 (10 pages).

Bowen, H. J. M., (1979). Environmental chemistry of the elements, Academic Press, London, 333.

Broadley, M. R.; White, P. J.; Hammond, J. P.; Zelko, I.; Lux, A., (2007). Zinc in plants. New Phytol., 173 (4), 677-702 (26 pages).

Carver, G. A., (1972). Glacial geology of the mountain lakes wilderness and adjacent parts of the cascade range, Oregon. Ph.D. Dissertation, University of Washington, Seattle.

Chapman, P. M., (2000). The sediment quality triad: Then, now and tomorrow. Int. J. Environ. Poll., 13 (1-6), 351356 (6 pages).

Davis, J. B., (1973). Statistic and data analysis in geology, Wiley International, New York, 456-473 (18 pages).

De, A. K., (1987). Environmental chemistry, Wiley Eastern Ltd., New Delhi.

Forstner, U., (1985). Chemical forms and reactivities of metal in sediments, in: Leschber, R.; Davis, E. D.; Hermite, P. L., Elsevir (Eds.), London, 1-30 (31 pages).

Forstner, U.; Ahlf, W.; Calmano, W.; Kersten, M., (1990). Sediment criteria development, In: Helling, D.; Rothe, P.;
Forstner, U.; Stoffers, P. (Eds.), sediments and environmental geochemistry: selected aspects and case histories, Berlin, 311-338 (28 pages).

Gibs, R. J., (1973). Mechanism of trace metal transport in rivers. Sci., 180 (4081), 71-73 (3 pages).

Harrison, R. J.; Dunin-Borkowski, R. E.; Putnis, A., (2002). Direct imaging of nanoscale magnetic interactions in minerals. Proc. Natl. Acad. Sci., 99 (26), 16556-16561 (6 pages).

Harte, J.; Holdren, C.; Schneider, R.; Shirley, C., (1991). Toxics A to $\mathrm{Z}$, a guide to everyday pollution hazards, University of California Press, Oxford, 478.

Horowitz, A. J.; Meybeck, M.; Idlafkih, Z.; Biger, F., (1999). Variations in trace element geochemistry in the Seine river basin based on floodplain deposits and bed sediments. Hydrol. Processes, 13 (9), 1329-1340 (12 pages).

Huu, H. H.; Rudy, S.; Damme, A. V., (2010). Distribution and contamination status of heavy metals in estuarine sediments near Cau Ong harbor, Ha Long Bay. Vietnam, Geol. Belgica, 13 (1-2), $37-47$ (11 pages).

Jain, C. K.; Singhal, D. C.; Sharma, U. K., (2005). Metal pollution assessment of sediment and water in the river Hindon, India. Environ. Monit. Assess., 105 (1-3), 193207 (15 pages).

Jiao, Y.; Grant, C. A.; Bailey, L. D., (2004). Effects of phosphorus and zinc fertilizer on cadmium uptake and distribution in flax and durum wheat. J. Sci. Food Agr., 84 (8), 777-785 (9 pages).

Karbassi, A. R; Monavari, S. M.; Nabi Bidhendi, Gh. R.; Nouri, J., (2008). Metal pollution assessment of sediment and water in the Shur River. Environ. Monit. Assess., 147 (1-3), 107116 (10 pages).

Kho, F. W. L.; Law, P. L.; Lai, S. H.; Oon, Y. W.; Ngu, L. H.; Ting, H. S., (2009). Quantitative dam break analysis on a reservoir earth dam. Int. J. Environ. Sci. Tech., 6 (2), 203-210 (8 Pages).

Kirk, R. E.; Othmer, D. F., (1985). Kirk-Othmer Concise Encyclopedia of Chemical Technology, Wiley, New York.

Lascelles, K.; Morgan, L. G.; Nicholls, D.; Beyersmann, D., (2005). "Nickel Compounds" in Ullmann's Encyclopedia of Industrial Chemistry, Wiley-VCH, Weinheim.

Lide, D. R., (1998). Handbook of Chemistry and Physics (87 ed.), CRC Press, Boca Raton, FL.

Martin, J. M.; Meybeck, M., (1979). Elemental mass-balance of material carried by major world rivers, Mar. Chem., 7 (3), 173-206 (34 pages).

Mediolla, L. L.; Domingues, M. C. D.; Sandoval, M. R. G., (2008). Environmental Assessment of an Active Tailings Pile in the State of Mexico (Central Mexico), Res. J. Environ. Sci., 2 (3), 197 - 208 (12 pages).

Opuene, K.; Okafor, E. C.; Agbozu, I. E., (2008). Partitioning characteristics of heavy metals in a non-tidal freshwater ecosystem. Int. J. Environ. Res., 2 (3), 285-290 (6 pages).

Priju, C. P.; Narayana, A. C., (2007). Heavy and Trace Metals in Vembanad Lake Sediments. Int. J. Environ. Res., 1 (4), 280-289 (10 pages).

Rayner-Canham, G.; Overton, T., (2003). Descriptive Organic Chemistry, Macmillan.

Rosental, R.; Eagle, G. A.; Orren, M. Y., (1986). Trace metal distribution in different chemical fractions of near shore marine sediments. Estuarine Coastal Shelf Sci., 22 (3), 303324 (22 pages). 
Samans, C. H., (1949). Engineering Metals and their Alloys, MacMillan.

Schuurmann, G.; Market, B., (1998). Ecotoxicology, ecological fundamentals, chemical exposure, and biological effects. Wiley, New York.

Stamatis, N.; Kamidis, N.; Sylaios, G., (2006). Sediment and suspended matter lead contamination in the gulf of Kavala, Greece. Environ. Monit. Assess., 115 (1-3), 433-449 (17 pages).

Sutherland, R. A., (2000). Bed sediment-associated trace metals in an urban stream, Oahu, Hawaii. Environ. Geol., 39 (6), $611-627$ (17 pages).

Taghinia Hejabi, A.; Basavarajappa, H.T.; Qaid Saeed, A.
M., (2010). Heavy metal pollution in Kabini river sediments. Int. J. Environ. Res., 4 (4), 629-636 (8 pages).

Turekian, K. K.; Wedepohl, K. H., (1961). Distribution of the elements in some major units of earth's crust. Bull. Geol. Soc. Am., 72 (2), 175-192 (18 pages).

Van de Guchte, C., (1992). The sediment quality triad:an integrated approach to assess contaminated sediments, in: P. J. Newman, M. A. Piavaux, R. A. Sweeting, (Eds.), River water quality, ecological assessment and control, Brussels, 417-423 (7 pages).

Wiberg, V. E.; Wiberg, N.; Holleman, A. F., (2001). Inorganic Chemistry, Academic Press.

\section{AUTHOR (S) BIOSKETCHES}

Karbassi, A. R., Ph.D., Assistant Professor, Faculty of Environment, University of Tehran, No. 25 Ghods St. Enghelab St. Tehran Iran. Email:arkarbassi738@yahoo.com

Torabi, F., M.Sc. student of Environmental Engineering, Environmental Faculty, Univ. of Tehran, Iran

Email: fatemeh.torabi@gmail.com

Ghazban, F., Ph.D., Associate Professor, Faculty of Environment, University of Tehran, No. 25 Ghods St. Enghelab St. Tehran Iran. Email:fghazban@ut.ac.ir

Ardestani, M., Ph.D., Assistant Professor, Faculty of Environment, University of Tehran, No. 25 Ghods St. Enghelab St. Tehran Iran Email: ardestan@ut.ac.ir

How to cite this article: (Harvard style)

Karbassi, A. R.; Torabi, F.; Ghazban, F.; Ardestani, M., (2011). Association of trace metals with various sedimentary phases in dam reservoirs. Int. J. Environ. Sci. Tech., 8 (4), 841-852. 